\title{
Cómo organizarse profesionalmente para asesorar, elaborar y asegurar reportes de gestiones orientadas a la sostenibilidad
}

\author{
Strategies to Organise Professionally to Advise, Prepare and Assure \\ Sustainability-Oriented Management Reports \\ Como se organizar profissionalmente para assessorar, elaborar \\ e assegurar relatórios de gestões orientadas à sustentabilidade
}

\section{Eduardo Ingaramo}

Universidad Blas Pascal, Córdoba,

Argentina

E-mail:ingacasa1@gmail.com

Fecha de recepción: 18/09/2019

Fecha de aceptación: 01/06/2020

Palabras clave

- Sostenibilidad

- Organización

- Servicios profesionales

- Fundamentos teóricos

- Formación profesional

\section{Resumen}

El trabajo busca responder la pregunta que plantea el título «iCómo organizarse para prestar servicios profesionales de asesoramiento, elaboración y aseguramiento de reportes de gestiones orientadas a la sostenibilidad?» orientado a actuales o futuros profesionales en ciencias económicas en general.

La pregunta no tiene una respuesta simple 0 directa. Se trata de la modificación de estructuras inveteradas en las empresas y estudios profesionales que mayoritariamente aún no ven en nuestro país las ventajas de gestiones sostenibles.

La propuesta está desarrollada a modo de ensayo ${ }^{1}$ en el que basándome en fundamentos teóricos de distintas vertientes del pensamiento — socioeconómico, ambiental, político y humanista — planteo un camino a transitar para lograrlo.

Considerando la sostenibilidad personal y profesional de millenials y centenials, el mercado de los servicios profesionales de consultoría y auditoría, sus formas de organización existentes, hasta la elaboración de un plan de negocios de la organización de servicios profesionales. 
Keywords

- Sustainability

- Organization

- Professional services

- Theoretical foundations

- Vocational training

Palabras-chave

- Sustentabilidade

- Organização

- Serviços profissionais

- Fundamentos Teóricos

- Formação Profissional
La intención es que el trabajo sea útil para su uso en instancias de formación universitaria de profesionales en ciencias económicas orientados a la sostenibilidad.

\section{Abstract}

The objective of this research work is to answer the question "How can we organise to provide professional services to advise, prepare and assure sustainability-oriented management reports?" and it is aimed at professionals in Economics both in the present and for the future.

There is no simple or direct answer to this question. It is about changing deeply-rooted structures in most companies which do not see the advantages of sustainable management in our country yet.

This proposal is presented as an essay based on theoretical arguments from different socioeconomic, environmental, political and humanist schools of thought. It considers factors which include the personal and professional sustainability of millennials and centennials, the market of professional services such as consultancy and audit, their existing organisational forms and the development of a business plan for the organisation of professional services.

The purpose of this work is to be useful for the training of sustainabilityoriented professionals in the field of Economics.

\section{Resumo}

0 trabalho procura responder a pregunta que coloca 0 título "Como se organizar para oferecer serviços profissionais de assessoramento, elaboração e asseguramento de relatórios de gestões orientadas à sustentabilidade? Orientado a profissionais da área das ciências econômicas em geral, atuais ou futuros.

A pergunta não tem uma resposta simples ou direta. Trata-se da modificação de estruturas tradicionais nas empresas e estudos profissionais, que na sua maioria ainda não vem as vantagens de gestões sustentáveis no nosso país.

A proposta é desenvolvida no formato de ensaio. Com base em fundamentos teóricos de diferentes vertentes do pensamento - sócioeconômico, ambiental, político e humanista - apresento um caminho a transitar para consegui-lo.

Considerando a sustentabilidade pessoal e profissional de millennials e centennials, o mercado dos serviços profissionais de consultoria e auditoria, suas formas de organização existentes, até a elaboração de um plano de negócios da organização de serviços profissionais.

A intenção, é que 0 trabalho seja útil para seu uso em instâncias de formação universitária de profissionais em ciências econômicas orientados à sustentabilidade. 